\title{
Investigation of Lipids Profiles of Nigella, Lupin and Artichoke Seed Oils to be Used as Healthy Oils
}

\author{
Minar Mahmoud M. Hassanein, Safinaz M. El-Shami* and \\ Mohammed Hassan El-Mallah \\ National Research Centre, Fats and Oils Dept. (33 Tahrir St.Dokki, Cairo, EGYPT)
}

\begin{abstract}
Nigella sativa, lupin and artichoke seed oils have been investigated. The oils were subjected to detailed studies using gas chromatographic analysis (GLC) for fatty acids (FA, as methyl esters) and whole sterols (as silyl derivatives). Whereas, high pressure liquid chromatography (HPLC) was employed for determination of molecular species of triacylglycerols (TAG), four sterol lipids (free and acylated sterols, FS and AS, and free and acylated sterylglycosides, FSG and ASG, as their anthroylnitrile derivatives) as well as tocopherol patterns $(T)$. The results showed that the three seed oils are rich in oleic and linoleic acids whereas, lupin had high linolenic acid content. It was found that the TAGs of the three oils showed some similarity with sunflower oil. Lupin oil had higher sterol content and it was very rich in campe- and $\beta$-sitosterol. Nigella sativa oil had a high content of isofucosterol, whereas artichoke oil was unique in having a high content of 5-stigma-, 7-stigma-, and avena- sterol. Concerning the FS and AS, Nigella sativa oil had the highest content, whereas artichoke oil had the highest content of FSG and ASG. Nigella sativa and lupin oils contained over $90 \% \gamma$-T while, artichoke oil comprised about $100 \% \alpha$-T. It is recommended to use the three oils as healthy oils and folk medicine.
\end{abstract}

Key words: artichoke , Lupin, Nigella, sterol lipids, triacylglycerols, tocopherols

\section{INTRODUCTION}

Nutrition and healthy care are strongly interconnected and many plant parts as well as the seeds have been used for culinary and medical purposes. Screening analysis, undertaken in our laboratory, revealed that there is still a lack of data concerning herbal plant seed oils, namely, Nigella sativa (black cumin, Ranunculacae), Lupinus termis (Leguminosae) and artichoke(Cynara scolymus, Compositae).

Nigella sativa is indigenous and grows well in different localities in Egypt. The seeds of this plant have been used by ancient Egyptians and Arabs ${ }^{1}$ in the treatment of asthma, cough and headache. They are also used as a carminative and flavouring agent to bread. Nigella sativa seeds are used for culinary purposes but in particular as folk medicine and contained minor lipids components which are beneficial for health ${ }^{2-4)}$. On the other side, its oil contains linoleic acid (56.0\%), oleic acid (25.0\%) and plamitic $\operatorname{acid}(11.0 \%)$ and is a rich source of $\beta$-sitosterol ${ }^{5-8)}$.

Concerning lupin seeds, it was reported that white lupin contains 4.0 to $23.0 \%$ oil which is characterized by a bal- anced fatty acids composition with total saturated fatty acids $\leq 10.0 \%$ and total unsaturated fatty acids $\leq 90.0 \%$ of which 32.0 to $50.0 \%$ is oleic acid, 17.0 to $47.0 \%$ is linoleic and 3.0 to $11.0 \%$ is linolenic acid ${ }^{9-11}$. With reference to its unsaponifiable fraction, it constitutes up to $5.0 \%$ of lupin total lipids, of which sterols and triterpene alcohols represent 25.0 and $22.0 \%$ respectively ${ }^{12)}$.

As far as one knows, there are some varieties of artichoke plant that are used as edible vegetable and also in medical purposes. Few varieties, for example "Roman" spiny variety, principally cultivated for medical purposes, produces high yield of seeds rich in oil ${ }^{13)}$. The oil content of the seeds of this variety is $20.5 \%$ and the fatty acid composition comprises oleic, linoleic and linolenic acids (26.73, 58.89 and $0.25 \%$ respectively). Whereas, sterol patterns elucidated the presence of cholesterol, campesterol, $\Delta^{5}$ stigmasterol, $\beta$-sitosterol, $\Delta^{7}$ stigmasterol and $\Delta^{7}$-avenasterol $(0.2,12.8,16.2,45.6,18.4-6.6 \% \text { respectively })^{14)}$.

In spite of different applications on nigella, lupin and artichoke, their seed oils are used for culinary and medical purposes. The objective of this work is to focus on the elu-

\footnotetext{
*Correspondence to: Safinaz M. El-Shami, National Research Centre, Fats and Oils Department, 33 Tahrir St.Dokki, Cairo, EGYPT E-mail: saelshami@yahoo.com Accepted August 7, 2010 (received for review April 29, 2010) Journal of Oleo Science ISSN 1345-8957 print / ISSN 1347-3352 online http://www.jstage.jst.go.jp/browse/jos/
} 
cidation of the important lipid profiles which have not been investigated before, particularly the bioactive sterol lipids. Thus it was aimed to investigate the different lipids of the selected oils including FAs, TAGs with distributed fatty acids, whole sterols, sterol lipids (FS, AS, ASG and FSG) as well as $\mathrm{T}$ patterns. The results were compared with two conventional seed oils, namely, sunflower and cottonseed. It is worthy to mention that Egypt produces about 2384 ton of lupin and 146 ton of Nigella sativa/year. Their oils are extensively used as folk medicine and they are sold in private centers for this purpose. However, artichoke(Romanian strain) is recently cultivated in Egypt and accordingly there are no sufficient informations about its production. It is cultivated to use its leaves in pharmaceutical purposes and the seeds (rich in oil) are produced as a byproduct.

Recent methods of analysis have been applied to give reliable and accurate results of the compounds even if they are in minute quantities.

\section{EXPERIMENTAL PROCEDURES}

\subsection{Materials}

The seeds of Nigella sativa (local variety, freshly harvested, season 2008) were purchased from the local market. While artichoke(Romanian strain, spiny captiula, not edible but cultivated for medicinal purposes) was cultivated in Moshtohor experimental station(Zagazig Egypt, season 2008). Lupin and two oil seeds belonging to sunflower(Helianthus annus) and cottonseed (Gossypium barbadense, Giza 74) were cultivated in the National Research Centre Experimental Agricultural Station(El Qanater El-Khairiya Egypt, season 2008)

Three lots of each kind of seeds were ground, separately, to pass 60-mesh size with electric mill. Each lot was directly extracted two times with chloroform-methanol $(2: 1 \mathrm{v} / \mathrm{v})$ with intermittent stirring to extract the oil. The extracts were combined, filtered and dried over anhydrous sodium sulphate and the solvent was removed off by rotary evaporator under reduced pressure at $50^{\circ} \mathrm{C}$. The resulting three oil samples for each kind of seeds were mixed to obtain a representative oil sample. The oil samples were kept in well stoppered dark containers at $0^{\circ} \mathrm{C}$ (to protect them from autoxidation) until use. The oil content was calculated on dry basis ${ }^{15)}$.

Authentic samples of mixed FAs methyl esters (C14C24 saturated and unsaturated) and a mixture of tocopherols $(\alpha, \beta, \gamma$ and $\delta$ ) were purchased from Sigma Chemical Co. 1-Anthroyl and 9-anthroyl nitriles (1-AN and 9-AN) and the catalyst (which was used in the preparation of the sterols derivatives) were kindly supplied by T. Murui, Nisshin Oil Mills, Japan. Sterols mixture of cottonseed oil(Gossypium barbadense Giza 74), as a reference sample, was laboratory prepared and its composition was cholesterol, campe-, 5-stigma-, $\beta$-sito-, isofuco- and avena-sterol $(0.4,9.0,2.1$, $84.0,4.0$ and $0.5 \%$ respectively).

\subsection{Methods}

\subsubsection{Fatty acids pattern}

The oil was converted into methyl esters by transesterification with $5 \%$ methanolic hydrogen chloride ${ }^{16)}$. Transesterification reaction was monitored with the help of TLC using silica gel G plates and n-hexane/diethyl ether/acetic $\operatorname{acid}(80 / 20 / 1, v / v / v)$ as a developing solvent. Hewlett Packard-HP 5980-A gas chromatograph was used for the analysis of the mixed FAs methyl esters under the following operating conditions: column, DB-23 (0.32 $\mathrm{mm} \times 30 \mathrm{~m})$; temperature programming, $150-230^{\circ} \mathrm{C}, 3^{\circ} \mathrm{C} / \mathrm{min}$; injector, $230^{\circ} \mathrm{C}$; detector, FID at $240^{\circ} \mathrm{C}$, carrier gas, helium at flow rate of $1.3 \mathrm{~mL} / \mathrm{min}$ and split ratio, $100: 1$. Calibration was made using standard fatty acid methyl esters and the results were recorded by an electronic integrator as peak area percent.

2.2.2 Triacylglycerols pattern

TAG molecular species profile was elucidated using HPLC instrument (Toyo-Soda-CCPM). An oil sample in chloroform $(300 \mathrm{mg} / \mathrm{mL})$ was prepared and $10 \mu \mathrm{L}$ of this solution was injected into the column, ODS capcel Pack, $\mathrm{C}_{18}$ $(4.4 \mathrm{~mm} \times 10 \mathrm{~cm})$. Gradient elution with acetonitrile: dichloromethane (starting from 90: 10 to 35: $65 \mathrm{v} / \mathrm{v}$ ) in 150 minutes was conducted. FID detector (with moving band, Tracor 945) was attached to the instrument.

The carbon number assignment for the separated peaks was determined using HPLC chromatogram for soybean oil taken as a reference containing 29 TAGs starting with trilinolein $(\mathrm{XXX})$ and terminating with tristearin $(\mathrm{SSS})^{17,18)}$ The eluted TAGs were separated according to their equivalent carbon number (ECN) or critical pairs. The elution sequence was the same as reported before ${ }^{19)}$. Designations of TAGs do not imply the positional acyl distribution in TAG molecules but a mixture of TAG isomers. The following coding was used for fatty acyls : $\mathrm{X}=$ linolenic, $\mathrm{L}=$ linoleic, $\mathrm{O}=$ oleic, $\mathrm{S}=$ stearic and $\mathrm{P}=$ palmetic .

2.2.3 Whole sterols

Whole sterols mixture was isolated from the prepared unsaponifiable fraction ${ }^{15)}$ by preparative TLC on silica gel G plates ( $0.5 \mathrm{~mm}$ thickness) using chloroform/diethyl ether/ acetic acid (95/4/1 by volume) as a developing solvent. The sterol zone was located with the help of standard $\beta$-sitosterol $\left(\mathrm{R}_{\mathrm{f}}=0.16\right)$ applied alongside the sample prior to development. The sterol zone was scraped off the plate and thoroughly extracted with moistened diethyl ether and the solvent was distilled off. The sterols mixtures of the sample and the reference were, separately, converted into trimethylsilyl derivatives ${ }^{16)}$ (TMS).

Hewlett Packard-HP 5890-A gas chromatograph, was employed for the analysis using the following operating 
conditions: column, DB-17 $(0.32 \mathrm{~mm} \times 15 \mathrm{~m}, 0.25 \mu \mathrm{m}$ coating) at $250^{\circ} \mathrm{C}$; detector, FID at $260^{\circ} \mathrm{C}$; carrier gas, helium $(8.6 \mathrm{~mL} / \mathrm{min})$ and split ratio, 35: 1 . An automatic integrator was coupled directly to the detector. TMS of the reference sterols mixture (containing known percentages of sterols) was used for identification and quantification of the sterols in each oil sample. The area under each peak was measured by the automatic integrator ${ }^{16)}$.

2.2.4 Free and acylated sterols

The isolation of FS and AS, their derivatization into 9-AN and their HPLC determinations were carried out according to El-Mallah, et al. ${ }^{17,18)}$ and Wanaka and Murui ${ }^{20)}$. HPLC of sterols 9-AN was conducted under the following conditions: reversed phase column, ODS-1250Y, Senshu Pack (4.6 mm $\times 250 \mathrm{~mm})$; detector, fluorescence; excitation and emission wave lengths set at 360 and $460 \mathrm{~nm}$; isocratic elution using acetonitrile/ dichloromethane (75/25, v/v) at flow rate of $1 \mathrm{~mL} / \mathrm{min}$. The identification of the peaks was designated according to Wanaka and Murui ${ }^{20)}$.

2.2.5 Free and acylated sterylglycosides profiles

The procedure of separation of FSG and ASG from the oil, their derivatization into SG-1-AN and HPLC analysis were carried out according to El-Mallah, et $a l .{ }^{17,18)}$ and Murui et $a l .^{21)}$. HPLC instrument equipped with UV detector(Toso, UV 8000) and ODS Wakosil-5, C18 (6.4 mm × 250 $\mathrm{mm}$ ) was used for SG-1-AN analysis. Gradient elution with acetonitrile/dichloromethane (from 50/50 to 68/32, v/v) was used and the absorption was measured at $254 \mathrm{~nm}$. It is noteworthy to mention that this method is sensitive to 0.5 nanogram of SG. The identification of the peaks was designated as reported by Murui, et al. ${ }^{21)}$.

2.2.6 Tocopherols pattern

HPLC analysis of tocopherols, in the sample as well as the standard tocopherols mixture, was carried out using Toyo-Soda-CCPM HPLC instrument. An oil sample(10 g) was dissolved in n-hexane to make $10 \%$ solution and $10 \mu \mathrm{L}$ was injected into silica column(YMC-A-012, 6.0 $150 \mathrm{~mm}$ ). Isocratic elution was conducted using n-hexane: isopropyl alcohol (100: 0.5, by volume) as mobile phase, at a flow rate of 1-2 mL/min. Hitachi-650-10S fluorescence detector was used. Spectral absorption was set at excitation and emis- sion wavelengths of 295 and $325 \mathrm{~nm}$ respectively. The conditions were optimized to elute $\delta$-T after $10 \mathrm{~min}$; the results were automatically recorded as peak areas percentages by electronic integrator. From the peak area and the corresponding weight of each individual standard $\mathrm{T}$, the weight of each individual $\mathrm{T}$ in the oil (ppm) can be calculated ${ }^{17,22)}$.

All the tested data were the mean of two concordant replicates and the difference did not exceed more than $0.2-0.4$.

\section{RESULTS}

\subsection{Oil content}

The seeds of nigella, lupin and artichoke contained 33.0, 10.0 and $24.0 \%$ oil respectively, whereas the seeds of sunflower and cottonseed contained 24.0 and $25.0 \%$ respectively on the dry weight basis. It can be seen that nigella seed oil has the highest oil content in comparison to the other seed oils.

\subsection{Fatty acids}

The FAs compositions are recorded in Table 1. The results showed marked variations in the FA components of the three non-conventional seed oils (nigella, lupin and artichoke) in comparison with those of the conventional vegetable oils (cotton and sunflower seed oils) used in edible purposes. It was found that these non-conventional oils were rich in unsaturated fatty acids which constituted 84.1, 84.2 and 84.7\% for nigella, lupin and artichoke seed oils respectively. Among the unsaturated fatty acids, linoleic acid was the major constituent in nigella and artichoke seed oils (57.0 and 53.5\% respectively) followed by oleic $\operatorname{acid}(24.2$ and $30.9 \%$ respectively). Whereas, oleic acid $(44.0 \%)$ was the main constituent in lupin seed oil followed by linoleic acid (23.4\%). In addition, lupin seed oil is unique in having a high concentration of linolenic acid $(9.9 \%)$. Concerning the saturated fatty acids, palmetic acid was the major constituent in the three oils (12.3, 7.5 and $11.3 \%$ for nigella, lupin and artichoke seed oils respectively).

Table 1 Fatty acids profiles of the selected oils

\begin{tabular}{|c|c|c|c|c|c|c|c|c|c|c|c|c|c|c|}
\hline \multirow{3}{*}{ Oil } & \multicolumn{14}{|c|}{ Fatty acid composition (\%) } \\
\hline & \multirow{2}{*}{ 14:0 } & \multirow{2}{*}{$16: 0$} & \multirow{2}{*}{$16: 1$} & \multirow{2}{*}{$18: 0$} & \multicolumn{2}{|c|}{$18: 1$} & \multirow{2}{*}{$18: 2$} & \multirow{2}{*}{$18: 3$} & \multirow{2}{*}{ 20:0 } & \multirow{2}{*}{$20: 1$} & \multirow{2}{*}{$20: 2$} & \multirow{2}{*}{$22: 0$} & \multirow{2}{*}{$22: 1$} & \multirow{2}{*}{$24: 0$} \\
\hline & & & & & $n-9$ & $n-7$ & & & & & & & & \\
\hline Nigella & 0.20 & 12.3 & 0.20 & 3.4 & 22.4 & 1.8 & 57.0 & 0.30 & - & 0.40 & 2.0 & - & - & - \\
\hline Lupin & 0.10 & 7.5 & 0.30 & 1.9 & 41.9 & 2.1 & 23.4 & 9.9 & 1.1 & 4.2 & 0.50 & 4.1 & 1.9 & 1.1 \\
\hline Artichoke & 0.10 & 11.3 & 0.10 & 3.2 & 30.2 & 0.70 & 53.5 & - & 0.40 & 0.20 & - & - & - & 0.30 \\
\hline Sunflower & 0.15 & 6.0 & 0.14 & 3.5 & 44.0 & 0.60 & 43.51 & - & 0.35 & 0.25 & - & 1.0 & - & 0.50 \\
\hline Cottonseed & 1.0 & 25.0 & 0.80 & 3.3 & 18.0 & 1.0 & 49.5 & 0.35 & 0.44 & - & - & 0.40 & - & 0.30 \\
\hline
\end{tabular}


Comparing FA profiles of the three non-conventional oils used for culinary and medical purposes with those oils, conventionally, used for edible purposes, it could be noticed that there were some variation in the FA profiles as shown in Table 1.

\subsection{Triacylglycerols molecular species}

HPLC analysis of TAGs of the five oils under investigation are shown in Table 2. TAGs were arranged according to their equivalent carbon numbers $(\mathrm{ECN})$ values ranging from 36 to 50. It was found that LLL, LLO, LLP, LOO and LOP were the major components in nigella and artichoke

Table 2 HPLC analysis of triacylglycerols molecular species of the selected oils

\begin{tabular}{|c|c|c|c|c|c|c|}
\hline \multirow{2}{*}{ TAG } & \multirow{2}{*}{$\mathrm{ECN}$} & \multicolumn{5}{|c|}{ Triacylglycerols (\%) } \\
\hline & & Nigella & Lupin & Artichoke & Sunflower & Cottonseed \\
\hline $\mathrm{XXX}$ & 36 & - & 0.1 & - & - & - \\
\hline XXL & 38 & - & 0.6 & - & - & 0.5 \\
\hline XLL & 40 & 0.4 & 1.5 & - & 0.2 & - \\
\hline $\mathrm{XXO}$ & 40 & - & 1.0 & - & - & - \\
\hline XXP & 40 & - & 0.2 & - & - & - \\
\hline LLL & 42 & 18.1 & 1.3 & 19.2 & 19.4 & 12.0 \\
\hline XLO & 42 & 0.3 & 4.9 & 0.3 & 0.2 & - \\
\hline XLP & 42 & 0.2 & 1.2 & - & 0.1 & 1.0 \\
\hline XXS & 42 & 0.1 & - & - & - & - \\
\hline LLO & 44 & 16.1 & 6.8 & 19.1 & 21.4 & 12.5 \\
\hline $\mathrm{XOO}$ & 44 & - & 6.5 & - & - & - \\
\hline LLP & 44 & 16.5 & - & 11.8 & - & 22.0 \\
\hline XLS & 44 & - & - & - & 8.5 & - \\
\hline XOP & 44 & - & 2.3 & - & - & 1.5 \\
\hline XPP & 44 & 0.2 & 0.1 & - & - & - \\
\hline LOO & 46 & 9.6 & 13.2 & 12.5 & 20.6 & 6.0 \\
\hline LLS & 46 & - & 6.7 & - & 13.2 & - \\
\hline LOP & 46 & 13.4 & - & 13.0 & - & 16.5 \\
\hline LPP & 46 & 2.2 & 0.4 & 2.3 & 1.4 & 13.0 \\
\hline $\mathrm{OOO}$ & 48 & 3.2 & 10.0 & 6.4 & 3.9 & 1.9 \\
\hline LOS & 48 & 3.1 & 3.0 & 2.6 & 4.6 & 1.5 \\
\hline OOP & 48 & 3.2 & 6.2 & 5.8 & 1.8 & 3.5 \\
\hline LSP & 48 & 1.0 & 2.0 & 1.1 & 1.1 & 2.4 \\
\hline POP & 48 & 1.2 & 2.2 & 1.6 & 0.2 & 5.0 \\
\hline XSS & 48 & - & 3.3 & - & - & - \\
\hline PPP & 48 & 0.2 & 1.5 & - & - & 0.2 \\
\hline OOS & 50 & 1.1 & 4.1 & 2.1 & 2.1 & 0.2 \\
\hline LSS & 50 & 0.3 & 0.6 & 0.3 & 0.5 & 0.1 \\
\hline POS & 50 & 0.7 & 1.4 & 0.9 & 0.8 & 1.1 \\
\hline SPP & 50 & - & 3.8 & 0.1 & - & 0.1 \\
\hline SOS & 50 & - & - & 0.1 & - & - \\
\hline SSP & 50 & - & 0.9 & - & - & - \\
\hline
\end{tabular}

ECN: Equivalent carbon number; TAG: Triacylglycerols X, L, O, S and P denote linolenic, linoleic, oleic, stearic and plamitic acids respectively 
seed oils. Whereas, LOO and OOO were major in lupin seed oil followed by LLO, XOO, LLS and LOS. In addition, lupin oil was characterized by its content of TAGs containing linolenic acid. It could be seen that all these TAGs were also found in sunflower and cottonseed oils but with some variations. It could be concluded that the HPLC method was efficient to separate TAG critical pairs which have the same ECN value.

\subsection{Whole sterols}

The whole sterol contents in nigella, lupin and artichoke seed oils, determined by preparative TLC, showed that they represent $0.2,1.2$, and $0.58 \%$ respectively of the total lipids.

Table 3 shows the whole sterols content as well as the sterols composition of the five oils. $\beta$-Sitosterol, the major sterol of most vegetable oils, was also the major constituent of nigella, lupin and artichoke seed oils. Lupin oil has the highest content of whole sterols. The results showed that lupin oil contained higher campesterol content than those present in nigella and artichoke oils. Concerning 5-stigmasterol, artichoke oil contained the highest amount of this sterol. Artichoke seed oil was unique in having spinasterol at a level of $2.2 \%$ in addition to high levels of 7-stigma- and avena- sterol which were not detected in nigella and lupin oils. It was also noticed that isofucosterol was found at a higher level in nigella oil than in lupin and artichoke oils.

In sunflower oil, 7-stigmasterol was present at nearly half the value of that in artichoke oil in addition to avena- sterol which was present at lower concentration than that in artichoke oil. It was noticed that $\beta$-sitosterol in the three nonconventional oils was lower than that of sunflower and cottonseed oils while, 5-stigmasterol in cottonseed oil was markedly lower $(3.0 \%)$ than that in the three non-conventional oils.

\subsection{Free and acylated sterols}

Sterols are present in vegetable oils in two forms, namely, free and acylated sterols. The HPLC results of FS and AS were recorded as percentage composition in Table 4.
The total content of FS and AS, isolated from the oils, were 1000,190 and $390 \mathrm{mg} / 100 \mathrm{~g}$ oil (1.0, 0.19 and $0.39 \%$ of the total lipid) for nigella, lupin and artichoke oils respectively. Concerning the FS and AS content of the three non-conventional oils, nigella oil contained the highest contents.

The FS and AS profiles showed the presence of isofuco-, campe/stigma- (unseparable pair) and $\beta$-sito- sterol in the three non- conventional oils but in different amounts. Avena-, spina- and 7-stigma-sterol in FS and AS fractions were only detected in artichoke seed oil. Artichoke oil was distinguished from nigella and lupin oils in having markedly higher percentage of 7-stigmasterol. Similar to artichoke, avenasterol was detected in sunflower oil and cottonseed oils in both fractions (FS and AS). It is noticed that spinasterol was present in sunflower at reasonable amount, whereas it was found in trace quantity in cottonseed oil, however in artichoke oil comparatively higher amount was detected. 7-Stigmasterol was found only at a reasonable percentage in sunflower oil in the form of sterol ester(AS) and was not detected in cottonseed oil whereas it was present at higher level only in artichoke oil. It was also, noticed that the sterol esters were present in higher percentage in nigella oil as well as cottonseed oil.

\subsection{Free and acylated sterylglycosides}

The results recorded in Table 5 show the total content of FSG and ASG of the five oils under investigation as ppm. Artichoke oil contained the highest content of total SG whereas; nigella oil contained the lowest content. It was found that $\beta$-sitosterol was the major component in both FSG and ASG fractions in the five oils under investigation followed by campe-/stigma-SG and isofuco-SG. It was also found that 7-stigma-SG and spina-SG were detected only in artichoke seed oil in both fractions.

Sunflower and cottonseed oils contained similar amounts of total SG which were markedly lower than the total content in artichoke oil. Avenasterol in FSG and ASG fractions was found in sunflower oil as well as the three non-conventional oils, but it was absent in cottonseed oil.

Table 3 GLC of whole sterols patterns, as silyl derivatives

\begin{tabular}{c|c|c|c|c|c|c|c|c}
\hline \multirow{2}{*}{ Oil } & \multirow{2}{*}{$\begin{array}{c}\text { Content } \\
\mathrm{mg} / 100 \mathrm{~g}\end{array}$} & $\begin{array}{c}\text { Campe } \\
\text { sterol }\end{array}$ & $\begin{array}{c}5 \text {-stigma } \\
\text { sterol }\end{array}$ & $\begin{array}{c}\beta \text {-sito } \\
\text { sterol }\end{array}$ & $\begin{array}{c}\text { Spina } \\
\text { sterol }\end{array}$ & $\begin{array}{c}\text { Isofuco } \\
\text { sterol }\end{array}$ & $\begin{array}{c}\text { 7-Stigma } \\
\text { sterol }\end{array}$ & $\begin{array}{c}\text { Avena } \\
\text { sterol }\end{array}$ \\
\cline { 3 - 10 } & 200 & 10.0 & 16.5 & 59.1 & - & 14.4 & - & - \\
\hline Nigella & 1200 & 27.9 & 11.2 & 54.6 & - & 6.3 & - & - \\
\hline Lupin & 580 & 9.5 & 22.7 & 33.1 & 2.2 & 0.4 & 25.7 & 6.4 \\
\hline Artichoke & 400 & 9.1 & 11.1 & 60.4 & - & 3.5 & 11.7 & 4.2 \\
\hline Sunflower & 480 & 10.0 & 3.0 & 81.3 & - & 5.0 & - & 0.7 \\
\hline Cottonseed & & & & & & & &
\end{tabular}


Table 4 Composition of free and acylated sterols as 9-AN-derivatives

\begin{tabular}{|c|c|c|c|c|c|c|c|c|}
\hline \multirow[b]{2}{*}{ Oil } & \multirow[b]{2}{*}{$\begin{array}{c}\text { State of } \\
\text { sterol }\end{array}$} & \multirow[b]{2}{*}{$\begin{array}{c}\text { Total } \\
\text { content } \\
\mathrm{mg} / 100 \mathrm{~g}\end{array}$} & \multicolumn{6}{|c|}{ Free and acylated sterol composition (\% ) } \\
\hline & & & $\begin{array}{l}\text { Avena } \\
\text { sterol }\end{array}$ & $\begin{array}{c}\text { Isofuco } \\
\text { sterol }\end{array}$ & $\begin{array}{l}\text { Spina } \\
\text { sterol }\end{array}$ & $\begin{array}{c}\text { Campe+ } \\
\text { Stigma } \\
\text { sterol }\end{array}$ & $\begin{array}{c}\text { 7-Stigma } \\
\text { sterol }\end{array}$ & $\begin{array}{l}\beta \text {-sito } \\
\text { sterol }\end{array}$ \\
\hline Nigella & $\begin{array}{c}\text { FS } \\
\text { AS } \\
\text { Total }\end{array}$ & $\begin{array}{c}630 \\
370 \\
1000 \\
\end{array}$ & - & $\begin{array}{l}9.0 \\
9.8\end{array}$ & - & $\begin{array}{l}40.8 \\
35.7\end{array}$ & - & $\begin{array}{l}50.2 \\
54.5\end{array}$ \\
\hline Lupin & $\begin{array}{c}\text { FS } \\
\text { AS } \\
\text { Total }\end{array}$ & $\begin{array}{c}90 \\
100 \\
190 \\
\end{array}$ & $\begin{array}{l}- \\
- \\
-\end{array}$ & $\begin{array}{c}8.3 \\
34.1 \\
- \\
\end{array}$ & $\begin{array}{l}- \\
-\end{array}$ & $\begin{array}{l}31.1 \\
14.6\end{array}$ & $\begin{array}{l}- \\
-\end{array}$ & $\begin{array}{l}60.6 \\
51.3\end{array}$ \\
\hline Artichoke & $\begin{array}{c}\text { FS } \\
\text { AS } \\
\text { Total }\end{array}$ & $\begin{array}{l}280 \\
110 \\
390 \\
\end{array}$ & $\begin{array}{c}6.7 \\
12.4\end{array}$ & $\begin{array}{c}5.7 \\
12.4\end{array}$ & $\begin{array}{l}4.6 \\
8.1\end{array}$ & $\begin{array}{l}30.0 \\
14.3\end{array}$ & $\begin{array}{l}23.0 \\
34.3\end{array}$ & $\begin{array}{l}30.2 \\
18.5\end{array}$ \\
\hline Sunflower & $\begin{array}{c}\text { FS } \\
\text { AS } \\
\text { Total }\end{array}$ & $\begin{array}{c}190 \\
60 \\
250 \\
\end{array}$ & $\begin{array}{l}3.5 \\
4.2\end{array}$ & $\begin{array}{l}5.8 \\
3.0\end{array}$ & $\begin{array}{l}2.0 \\
1.7\end{array}$ & $\begin{array}{l}18.5 \\
24.5\end{array}$ & $\begin{array}{c}- \\
5.0\end{array}$ & $\begin{array}{l}70.2 \\
61.6\end{array}$ \\
\hline Cottonseed & $\begin{array}{c}\text { FS } \\
\text { AS } \\
\text { Total }\end{array}$ & $\begin{array}{c}1200 \\
400 \\
1600\end{array}$ & $\begin{array}{l}1.0 \\
1.6\end{array}$ & $\begin{array}{c}8.0 \\
10.0\end{array}$ & $\begin{array}{l}0.3 \\
0.2\end{array}$ & $\begin{array}{c}8.7 \\
12.0\end{array}$ & $\begin{array}{l}- \\
-\end{array}$ & $\begin{array}{l}82.0 \\
76.2\end{array}$ \\
\hline
\end{tabular}

AN: Anthroylnitrile; FS: Free sterol and AS: Acylated sterol

Table 5 Composition of free and acylated sterylglycosides as 1-AN-deravatives

\begin{tabular}{|c|c|c|c|c|c|c|c|c|}
\hline \multirow[b]{2}{*}{ Oil } & \multirow{2}{*}{$\begin{array}{l}\text { SG } \\
\text { Type }\end{array}$} & \multirow{2}{*}{$\begin{array}{c}\text { Content } \\
\text { (ppm) }\end{array}$} & \multicolumn{6}{|c|}{ Free and acylated sterylglycosides composition (\%) } \\
\hline & & & Avena SG & $\begin{array}{c}\text { Isofuco } \\
\text { SG }\end{array}$ & $\begin{array}{c}\text { Spina } \\
\text { SG }\end{array}$ & $\begin{array}{c}\text { Campe+ } \\
\text { Stigma SG }\end{array}$ & $\begin{array}{c}\text { 7-stigma } \\
\text { SG }\end{array}$ & $\beta$-Sito SG \\
\hline Nigella & $\begin{array}{l}\text { FSG } \\
\text { ASG } \\
\text { Total }\end{array}$ & $\begin{array}{c}94 \\
158 \\
252\end{array}$ & $\begin{array}{c}- \\
0.6\end{array}$ & $\begin{array}{l}6.8 \\
6.8\end{array}$ & $\begin{array}{l}- \\
-\end{array}$ & $\begin{array}{l}24.1 \\
26.6\end{array}$ & $\begin{array}{l}- \\
-\end{array}$ & $\begin{array}{l}68.5 \\
68.6\end{array}$ \\
\hline Lupin & $\begin{array}{l}\text { FSG } \\
\text { ASG } \\
\text { Total }\end{array}$ & $\begin{array}{l}116.8 \\
122.9 \\
239.7\end{array}$ & $\begin{array}{l}0.3 \\
0.3\end{array}$ & $\begin{array}{l}8.6 \\
8.1\end{array}$ & $\begin{array}{l}- \\
-\end{array}$ & $\begin{array}{c}33 \\
32.9\end{array}$ & $\begin{array}{l}- \\
-\end{array}$ & $\begin{array}{l}58.1 \\
58.7\end{array}$ \\
\hline Artichoke & $\begin{array}{l}\text { FSG } \\
\text { ASG } \\
\text { Total }\end{array}$ & $\begin{array}{c}687 \\
313 \\
1000\end{array}$ & $\begin{array}{c}1.4 \\
-\end{array}$ & $\begin{array}{l}2 \\
-\end{array}$ & $\begin{array}{l}4.8 \\
2.5\end{array}$ & $\begin{array}{l}22 \\
23\end{array}$ & $\begin{array}{c}25.8 \\
24\end{array}$ & $\begin{array}{l}44.5 \\
50.5\end{array}$ \\
\hline Sunflower & $\begin{array}{l}\text { FSG } \\
\text { ASG } \\
\text { Total }\end{array}$ & $\begin{array}{l}210 \\
170 \\
380\end{array}$ & $\begin{array}{c}1.9 \\
1\end{array}$ & $\begin{array}{c}8 \\
3.5\end{array}$ & $\begin{array}{l}- \\
-\end{array}$ & $\begin{array}{l}12 \\
15\end{array}$ & $\begin{array}{c}1.8 \\
2\end{array}$ & $\begin{array}{l}76.3 \\
78.5\end{array}$ \\
\hline Cottonseed & $\begin{array}{l}\text { FSG } \\
\text { ASG } \\
\text { Total }\end{array}$ & $\begin{array}{c}250 \\
90 \\
340\end{array}$ & $\begin{array}{l}- \\
-\end{array}$ & $\begin{array}{c}7.5 \\
7\end{array}$ & $\begin{array}{l}- \\
-\end{array}$ & $\begin{array}{l}8 \\
8\end{array}$ & $\begin{array}{l}- \\
-\end{array}$ & $\begin{array}{c}84.5 \\
85\end{array}$ \\
\hline
\end{tabular}

AN: Anthroylnitrile; SG: Sterylglycoside; FSG: Free sterylglycoside and ASG: Acylated sterylglycoside

\subsection{Tocopherols}

The tocopherols profiles of the five oils under investigation are shown in Table 6. Concerning the total contents of tocopherols $(0.021,0.094$, and $0.031 \%$ of the total lipid respectively for nigella, lupin and artichoke), it could be no- ticed that lupin oil had the highest content of total tocopherols, whereas nigella and artichoke oils had comparatively lower amounts. Concerning the tocopherols composition of nigella and lupin oils, they contained high percentages, exceeding $90 \%$, of $\gamma$-tocopherol. Similar to sunflower oil, 
Table 6 Tocopherols profiles

\begin{tabular}{c|c|c|c|c|c}
\hline \multirow{2}{*}{ Oil } & \multirow{2}{*}{$\begin{array}{c}\text { Total T } \\
(\mathrm{ppm})\end{array}$} & \multicolumn{4}{|c}{ Tocopherol composition (\%) } \\
\cline { 3 - 6 } & 209 & 7.9 & - & 90.8 & 1.3 \\
\hline Nigella & 209 & $\gamma-\mathrm{T}$ & $\delta$-T \\
\hline Lupin & 939 & 3.4 & - & 93.6 & 3.0 \\
\hline Artichoke & 311 & 96.5 & - & 2.5 & 1.0 \\
\hline Sunflower & 670 & 95.5 & 2.6 & 1.0 & 0.9 \\
\hline Cottonseed & 630 & 44.8 & - & 55.0 & 0.2 \\
\hline
\end{tabular}

T: Tocopherol

$\alpha$-tocopherol was predominating in artichoke oil. Whereas $\alpha$-and $\gamma$-tocopherols were major in cottonseed oil. In addition, the tocopherols contents of sunflower and cottonseed oils were higher than those of nigella and artichoke oils.

\section{DISCUSSIONS}

The main unsaturated fatty acids of nigella, lupin and artichoke oils were oleic acid $\left(\mathrm{C}_{18: 1}\right)$ and linoleic acid $\left(\mathrm{C}_{18: 2}\right.$, n-6). Linoleic acid constituted 57.0, 23.4 and 53.5\% of the total fatty acids of the three oils respectively. Whereas, linolenic acid $\left(\mathrm{C}_{18: 3}, \mathrm{n}-3\right)$ constituted 0.3 and $9.9 \%$ in nigella and lupin oils respectively. According to the amounts of n-6 and n-3 in these seed oils, they can be considered as significant sources of essential fatty acids (EFA). Linoleic and linolenic acids are essential for the human body because they cannot be synthesized in the body. From this point of view, nigella, lupin and artichoke seed oils can be considered as valuable sources of dietary fat. It is reported that the EFA are necessary for the formation of the cell membrane, the development and function of the brain and nervous system, and for the production of hormone-like substances called eicosnoids (thromboxans, leukotriens, prostaglandins) in poultry and human. Also, it is known that the EFA play very important roles in human health and nutrition and are absolutely required for neonatal reti$\mathrm{nal}^{23-26)}$. It is also, reported that diet deficient in EFA can lead to poor growth ${ }^{26)}$.

The triacylglycerols molecular species containing n-6 fatty acid (present at high levels in the nigella and artichoke oils) were characterized by their contents of LLL, LLO, LLP, LOO, LOP and LPP. Whereas, the n-3 fatty acid was present in lower amounts only in lupin oil such as XLO, XLP, XOO and XOP. It is worthy to mention that the three seed oils show some similarities with sunflower and cottonseed oils in having, almost, the same TAGs but with different quantities.

Regarding the phytosterols (the four classes of sterol lipids, namely, FS, AS, FSG and ASG), they constituted the major portion of the unsaponifiable matter in most vegeta- ble oils ${ }^{27)}$. They possess a broad spectrum of therapeutic effects in animals and humans ${ }^{28-31)}$. In humans, consumption of plant-derived sterols particularly $\beta$-sitosterol (which is the main sterol in the nigella, lupin and artichoke oils) reduces blood pressure ${ }^{32)}$, serum cholesterol levels and the risk of chronic heart disease ${ }^{27,30)}$. Phytosterols also serve as intermediates for synthesis of hormonal sterols and other related pharmaceuticals ${ }^{28)}$. In addition, phytosterols, especially $\beta$-sitosterol, exhibit significant anti-inflammatory effects and antitumor properties ${ }^{28,30)}$. It is worthy to mention that SGs suppress the absorption of cholesterol and fatty acids in the intestine, i.e. they are considered as hypocholsterolemic component ${ }^{32)}$.

With respect to tocopherol(vitamin E) constituents, nigella and lupin oils contained more than $90 \% \gamma$ - tocopherol which is more potent constituent against lipid oxidation in the cell. Whereas, artichoke oil contained more than $96 \%$ of $\alpha$-tocopherol which has biological and nutritive effects ${ }^{31,33)}$. It can be seen that artichoke oil resembles sunflower oil in this respect. The interest in natural antioxidants, especially of vegetable origin, has recently increased. Natural antioxidants, especially tocopherols can protect the human body from free radicals that may lead to the aging process ${ }^{34)}$ and cause some chronic diseases including cancer, cardiovascular diseases and cataract as well as retarding lipid oxidative rancidity in foods ${ }^{35,36)}$. On the other hand, among the tocopherols present in foods, $\alpha$-tocopherol shows the highest vitamine $\mathrm{E}$ activity, thus making it the most important for human health and biological activity ${ }^{37)}$.

\section{CONCLUSIONS}

It can be concluded that the three non-conventional seed oils can be consumed for sustained culinary and/or folk medicinal purposes. In addition, these three non-conventional seed oils could be considered as good sources for functional food ingredients and may be a valuable source of dietary fat besides their use as folk medicine.

It is worthy to mention that this work was mainly, concerned with the analysis of lipid components in order to complete the picture, since there is a lack of data in this respect.

\section{ACKNOWLEDGEMENT}

The authors are grateful to Dr T. Murui of Nisshin Oil Mills (Japan), for his cooperation in many ways and supplying some standard compounds and help received. 


\section{References}

1) Ibn-Bitar; Ibn- Sina, A. Al-Kanun Fi Tebb. El-Halaby and Co. for Publishing and Distribution (1890).

2) Al-Okbi, S. Y.; Amar, N. A.; Soroor, K. H. A.; Mahmoud, D. A. Impact of natural oils supplements on disease activity and antioxidant state of Egyptian patients with heumatoid rthritis. Pharmacol. Med. J. Islamic Acad. Sci. 13(4), 161-171(2000).

3) EL-Ghorab, A. H. Supercritical fluid extraction of the Egyptian rosemary (rosmarinus officinais) leaves and Nigella sativa L seeds volatile oils and their antioxidant activities. J. Essential Oil-Bearing Plants 1, 67-77 (2003)

4) Houghton, P. J.; Zarka, R.; de las Heras, B.; Hoult, JR. Fixed oil of Nigella sativa and derived thymoqinone inhibit eicosanoid generation in lleukocytes and membrane lipid peroxidation. Planta Medica 61, 33-36 (1995).

5) Nergiz, C.; Otles, S. Chemical composition of Nigella sativa L. seeds. Food Chem. 48, 259-261 (1993).

6) Gupta, B. M.; Nath, R.; Srivastava N; Shanker, K.; Kishor K.; Bhargava, K. P. Anti- inflammatory and antipyretica activities of $\beta$-sitosterol. Planta Medica 39, 157-163 (1980).

7) Ramadan, M. F.; Morsel, J. T. Characterization of phospholipid composition of black cumin (Nigella sativa L.) seed oil. Nahrung 46 (4), 240-244(2002).

8) Nickavar, B.; Mojab, F; Javidnia, K.; Amoli, M. A. Chemical composition of the fixed and volatile oils of Nigella sativa L. from Iran. 1: Z Naturforsch [C].58 (9-10), 629-631 (2003).

9) Petterson, D. S. The use of lupins in feeding systems. Review, Asian Austral. J. Anim. Sci. 13, 861-882 (2000).

10) Bhardwaj, H. L.; Hamama, A. A.; Merrick, L. C. Genotypic and environmental effects on lupin seed composition. Plant Food. Nutr. 53, 1-13 (1998).

11) Hudson, B. J. F.; Fleetwood, J. G.; Lewis, J. I. Oil content, fatty acids and unsaponifiable lipids of lupin seed. J. Plant Foods 5, 15-21 (1983)

12) Anwar, H. A.; Harbans, B. L. Phytosterols, triterpene alcohols and phospholipids in seed oil from white lupin. J. Am. Oil Chemist's Soc. 18(11), 1039-1044 (2004).

13) Shahat, A. A. Chemical studies on cynara scolymus (artichoke) (family Compositae)cultivated in Egypt. M. Sc. Degree, University of Ain Shams, Faculty of Science, Cairo Egypt (1989).

14) Miceli, A.; De Leo, P. Extraction, characterization and utilization of artichoke-seed oil. Bioresource Technol. 57 (3), 301-302 (1996)

15) Official and tentative methods of the American oil chemists society. $3^{\text {rd }}$ ed. AOCS. Chicago. Illinois (1980).
16) Christie, W. W. The preparation of volatile derivatives of lipids. in Lipid Analysis. Chapter 4. Pergamon press. pp.85-102 (1973).

17) El-Mallah, M. H.; Murui,T.; El-Shami,S. Detailed studies on seed oil of silicornia SOS-7 cultivated at the Egyptain border of Red Sea. Grasas Y Aceites 45(6), 385-389 (1994).

18) El-Mallah M. H.; Murui,T.; El-Shami, S. New trends in determining the authenticity of corn oil. Grasas $Y$ Aceites 50 (1), 7-15(1999)

19) El-Hamdy, A. H. ; Perkins, E. G. High performance reversed phase chromatography of natural triglyceride mixtures: critical pair separation. J. Am. Oil Chem. Soc. 58, 867-872(1981).

20) Wanaka, K.; Murui, T. Determination of sterols in edible oils and fats by HPLC with fluorescence labeling. Yukagaku 40, 306-311 (1992).

21) Murui, T.; Wanaka, K.; Kuriyama, K. Determination of sterylglycosides as their 1- anthroylnitrile derivatives. Biosci. Biotech. Biochem. 25, 614-617(1993).

22) El-Shami, S.; Hassanein, M. M.; Murui,T.; El-Mallah, M. H. Studies of changes in patterns of fatty acids, sterols and tocopherols of oil during seed maturation part 1: sunflower seeds. Grasas Y Aceites 45(4), 227-231 (1994).

23) Udo, E. Fats and Oils: the complete guide to fats and oils in health and nutrition. Alive Books. Vancouver BC, Canada (1991).

24) Ertas, N. O.; Guler, T.; Ciftci, M.; Dalkilic, B. ; Yilmaz, O. The effect of a dietary supplement coriander seeds on the fatty acid composition of breast muscle in Japanese quail. Revue Med. Vet. 156 (10), 514-518(2005).

25) Harris, W. S.; Connor, W. E.; Alam, N.; Illingworth, D. R. Reduction of postprandial triglyceredemia in humans by dietary $\omega-3$ fatty acid. J. Lipid Res. 29, 1451-1460 (1988)

26) Institute of Medicine, Food and Nutritional Board. Dietary reference intakes for energy, carbohydrate, fiber, fat, fatty acids, cholesterol, protein and amino acids. National Academy Press. Washington DC (2002).

27) Gunstone, F. D.; Harwood, L. J.; Padly, B. F. The Lipid Handbook. Chapman \& Hall. Cambridge. p.571 (1986).

28) Ling, W. H.; Jones, P. J. Dietary phytosterols: a review of metabolism, benefits and side effects. Life Sci. 57, 195-206 (1995).

29) Moreau, R. A.; Whitaker, B. D.; Hicks, K. B. Phytosterols, and their conjugates in foods: structural diversity quantitative analysis, and health-promoting uses. Prog. Lipid Res. 41, 457-500(2002).

30) Clark, J., Tocopherols and sterols from soybean. Lipid Technol. 8, 111-114(1996).

31) Kamal-Eldin, A.; Appeleqvist, A. L. The chemistry and antioxidant properties of tocopherols and tocotrienols. 
Lipids 31, 671-701 (1996).

32） Murui, T.; Yoshikawa, M.; Takeuchi, H.; Fujii, S.; Mizobuchi, H. Effects of sterylglycosides from soybean on lipid indices in the plasma, liver, and feces of rats. Biosci. Biotech. Biochem. 58(3), 494-497(1994).

33) Bramley, P. M.; Elmadfa, I.; Kafatos, A.; Kelly, F.; Manios, J. Y.; Roxborough, H. E.; Schuch, W.; Sheehy, A. J. P.; Wagner H. K. Review, Vitamin E. J. Sci. Food Agric. 80, 913-938(2000).

34) Machlin, L. B.; Bendich, A. Free radical tissue damage: protective role of antioxidant nutrient. FASEBJ. 1
(44), 1-5(1987).

35） Kinsella, J. E.; Frankel, E.; German, B.; Kanner, J. Possible mechanisms for the role of antioxidants in wine and plant foods. Food Technol. 47, 85-89 (1993).

36) Mascio, P. D.; Murphy, M. E.; Sies, H. Antioxidant defence systems: Role of carotenoids, tocopherols and thiols, Am. J. Clin. Nutr. 53, 1945-2005 (1991).

37) Lai, L. S.; Chou, S. T.; Chao, W.W. Studies on the antioxidative activities of Hsian-tsao (Mesona procumbens Hems) leaf gum. J Agric. Food Chem. 49, 963-968 (2001). 